\title{
GÊNERO E CULTURA NAS CIÊNCIAS SOCIAIS \\ BRASILEIRAS: DEPOIMENTO DE UMA \\ PESOUISADORA COM NOME PRÓPRIO
}

\section{MAKING A NAME FOR ONESELF: CULTURE AND \\ GENDER IN THE BRAZILIAN SOCIAL SCIENCES \\ (INTERVIEW WITH HELOISA PONTES)}

\author{
Heloisa Pontes* \\ Camila Gui Rosatti** \\ Eliana Tavares dos Reis***
}

\section{Apresentação}

Camila Gui Rosatti Eliana Tavares dos Reis

Em um dossiê dedicado a pesquisas sobre mulheres que atuam em distintos domínios sociais, conversar com uma pesquisadora como Heloisa Pontes, que tanto colocou luz e foco na "questão de gênero", é uma forma de avançar no entendimento de quem são as cientistas sociais e como, por meio de suas inscrições e produções, contribuíram para que essa problemática se constituísse como dimensão fundamental de análise das relações sociais e de poder nas pesquisas universitárias.

0 relato de Heloisa se expande numa polifonia de elementos complexos, que são elegantemente colocados em harmo-

\footnotetext{
* Professora titular do Departamento de Antropologia da Universidade Estadual de Campinas - Unicamp - (Campinas/SP/BR). Bolsista de produtividade em pesquisa do CNPq. E-mail:helopontes1@gmail.com.br

** Pós-doutoranda na Faculdade de Arquitetura e Urbanismo (FAU) da Universidade de São Paulo - USP - (São Paulo/SP/BR), com estágio na École Normale Superiéure, projetos financiados com bolsa da FAPESP (processos: 2017/11458-9 e 2018/23451-1). Doutora em sociologia pela USP. E-mail: camila.rosatti@ gmail.com

**** Professora e pesquisadora do Programa de Pós-graduação em Ciências Sociais (PPGCSoc) da Universidade Federal do Maranhão - UFMA - (São Luís/MA/BR). Pesquisadora do CNPq e coordenadora do Laboratório de Estudos sobre Elites Politicas e Culturais (LEEPOC). E-mail: eliana1reis@terra.com.br
} 
nia na descrição de um trajeto biográfico precioso em muitos sentidos. A experiência pessoal e a vida profissional aparecem amarradas à (auto) análise social, situadas em seus contextos e com flashs de uma "teoria da prática”, que iluminam todo o depoimento. Assim, ofertando-nos o redesenho de seu percurso como mulher, docente e pesquisadora, temos acesso a diversos aspectos da vida de Heloisa, desde a jovem nascida em Belo Horizonte até a intelectual que se notabilizou com um "nome próprio": invariavelmente lidando com injunções, contingências e deslocamentos (às vezes impiedosos), assim como tecendo suas escolhas, entrelaçando parcerias, deixando fruir inclinações e papéis.

Sem o esforço frustrado e sempre parcial de antecipações e racionalizações de toda ordem, e sem aderir à narrativa laudatória centrada na primeira pessoa; Heloisa Pontes mobiliza as habilidades de uma escrita literária e os trunfos dos controles sociológicos para nos contar os eventos e as personagens marcantes de sua vida. E, pelas pistas reflexivas deixadas no caminho, tem toda a lucidez com relação ao peso da história coletiva sobre os elos (afetivos e profissionais) e as oportunidades, que também traçaram seu "destino".

$\mathrm{Na}$ trilha dos investimentos militantes e acadêmicos de sua orientadora de mestrado, Mariza Corrêa, Pontes fez parte de uma das primeiras gerações universitárias brasileiras que - com determinadas origens sociais e combinando gostos culturais, engajamento políticos e inserções em movimentos feministas - são responsáveis pela legitimidade dos estudos de gênero no Brasil. Não por acaso, Corrêa foi uma das fundadoras da revista Cadernos Pagu (cujas articulações inaugurais tiveram a influência de Elizabeth de Souza Lobo e das apropriações que fez do conceito de "gênero" proposto pela historiadora norte-americana Joan Scott), periódico entre os mais importantes e ao qual a entrevistada é formalmente associada.

Heloisa Pontes fez graduação em ciências sociais na UNICAMP e deu sequência aos estudos concluindo o mestrado na mesma universidade, na primeira metade da década de 1980, com a dissertação "Do palco aos bastidores: o SOS-Mulher e as práticas feministas contemporâneas". Vale lembrar que esse foi um período chave no fortalecimento da temática no Brasil - talvez ressonância tardia (principalmente por conta das condições restritivas de mobilização durante o regime militar) dos processos em curso nos Estados Unidos e Europa desde os anos 1960.

A configuração de um cenário público afeito à importação, adaptação e legitimação de uma diversidade de emblemas e identidades ligadas a "minorias", possibilitadas pela diversificação de perfıs e de repertórios legítimos de mobilização política, só foi mais substantivamente esboçado, no país, na segunda metade dos 1970 . Especialmente a partir dos meios universitários (acentuando o fortalecimento dos cursos de ciências humanas e sociais), espaço privilegiado, ao mesmo tempo, de encontros de afinidades (sociais, políticas e culturais), de socialização nas causas pertinentes à gramática democrática em pauta e de aquisição de saberes teóricos e de protocolos de luta compatíveis com as aspirações de transformação do mundo social.

A partir disso, as intelectuais do feminismo (em vias de profissionalização) se empenharam na realização de congressos, em campanhas e publicações de mulheres sobre mulheres, o feminino, as feministas, etc. 0 que viabilizou o realce das suas lutas no âmbito das reivindicações da esquerda em geral e a deflagração do paulatino e re- 
lativo descolamento das batalhas políticas mais amplas (preponderantemente conduzidas por lideranças masculinas), alicerçando pautas e bandeiras próprias. Com teorias e autores/as estrangeiras e nacionais consagradas, na década de 1990 há uma base sólida às reflexões sobre as lógicas e formas de dominação de gênero, categoria que permitiu abranger dimensões de análise e possibilidades de identifıcação, tendo como ponto de partida a não essencialização ou substancialização de clivagens e estereótipos fundantes das relações, divisões, papeis, etc. desiguais.

Importa aqui acompanhar as elaborações de uma mulher que agencia suas disposições e posições, inseparáveis, de sujeito e objeto, sem aderir às armadilhas implicadas na exaltação ou no desprezo das "questões de gênero". Ao longo de quase quarenta anos de pesquisa e mais de trinta de exercício da atividade docente como professora de antropologia na UNICAMP, Heloisa Pontes tem nos ajudado a perceber (pela descrição de suas práticas e pelo acúmulo de investigações) que as múltiplas intervenções no mundo social ganham inteligibilidade quando apreendidas "em relação", ou seja, na interação com outros marcadores sociais. Não somente classe, raça, como igualmente escolaridade, família, meio profissional e grupo geracional estão irremediavelmente enlaçados nas trajetórias e dão base para a ativação de atributos, conforme as diferentes dinâmicas sociais.

Sublinhamos a importância, nas suas pesquisas, dos momentos de mudanças morfológicas e revoluções simbólicas em diferentes espaços multifacetados (universidade, teatro, literatura e música), a partir dos quais podemos entender o que está em jogo na formação e nos ajustamentos entre novos ofertantes, públicos, produtos culturais e visões de mundo. A gama de componentes abarcados com firmes procedimentos analíticos, colocam as pesquisas de Pontes em patamar distante das abordagens amparadas em meras equivalências (muitas vezes tomadas como evidentes) construídas entre categorias sociais dominadas (notadamente as definidas por critério de raça e classe), cujos porta-vozes (ou pesquisadores e pesquisadoras que trazem, na gênese dos seus trajetos biográficos, as marcas do arbitrário das fronteiras sociais) geralmente acionam de forma bastante genérica e metafórica.

Inspiradas por sua análise primorosa de Gilda de Mello e Souza e o grupo de amigos uspianos que se reuniram em torno da revista Clima, tema de seu doutorado ${ }^{1}$, pedimos para ela nos contar sobre suas atividades na universidade e as condições de produção do seu próprio trabalho de pesquisa, sem descuidar de suas origens e trajetória de vida. Recebemos um relato vívido e cheio de detalhes - ora divertidos, emocionantes, sérios, sensíveis, críticos e analíticos - reconstituindo seu percurso. A formação escolar; as diferentes cidades em que morou; os arranjos familiares e as recomposições de sua própria família; a vida na universidade como estudante e como docente; a participação nos grupos de militância feminista; os encontros entre gerações que marcaram a formação dos grupos em que esteve vinculada; o trabalho coletivo por detrás dos livros; as parcerias intelectuais; o encontro amoroso; o enlace com os interesses de pesquisa (SOS-Mulher, grupo Clima, teatro paulista, música tropicalista, a casa e a do- 
mesticidade, etc.); e muito mais - posições, papéis e representações que pôde desempenhar ou coube reinventar, a de mãe, filha, esposa, parceira, amiga, madrasta, enteada, colega, esportista - passam por sua lente de reconstrução.

É um depoimento tão pulsante e cheio de vida que será, em tempos tão difíceis de crise política, sanitária e ataque à universidade, uma inspiração e um encorajamento para nós - estudantes, pesquisadores, cientistas sociais e, principalmente, mulheres -, continuarmos a seguir nossos projetos de desvendar o social, vislumbrando a potência de novas frentes de trabalho e dando novos sentidos aos estudos dos processos simbólicos.

\section{Com a palavra, Heloisa Pontes:}

Quando a Eliana e a Camila me convidaram para esta entrevista aceitei com entusiasmo. Estávamos em dezembro e no mês seguinte eu iria à Paris e me encontraria com a Camila, que estava por lá fazendo um estágio de pós-doutorado, com apoio da FAPESP. Por conta da nossa amizade e do dossiê que estamos organizando para a revista Brésil(s) sobre casas, gênero, raça e geração, pensei em usar uma parte do tempo disponível durante a estadia para começarmos a entrevista. A ideia, porém, caiu por terra assim que me instalei. Havia tanta exposição para ver, a cidade por percorrer - em caminhadas diárias que chegavam a $16 \mathrm{~km}$, segundo o aplicativo do celular - seminários para escutar, pessoas a encontrar, que achei melhor deixar a entrevista para a volta.

Acordamos que a faríamos no final de março, com a presença também de Rafael do Nascimento Cesar, meu orientando de doutorado com quem descobri recentemente o prazer de escrever artigos em conjunto. Até então só tinha feito isso com meu marido, o sociólogo Sergio Miceli. E, embora os resultados tenham sido estimulantes, a mistura de trabalho e casamento que marca a nossa relação não é, como vocês podem imaginar, isenta de tensões. Para quem conhece Sergio e sua exigência quase implacável no acabamento do trabalho intelectual - Camila sabe disso por ter sido orientada por ele no doutorado - entenderá de imediato o que quero dizer. Mas vamos deixar essa questão da parceria e das assimetrias para depois.

Por hora, o que quero sublinhar é a intromissão brutal e, incontornável, da pandemia - e do descalabro do governo - na vida de todos nós. A entrevista combinada para o final de março na minha casa em São Paulo, quando Camila já estaria de volta de um congresso nos Estados Unidos (que não aconteceu, como todos os outros eventos programados) e Rafael estaria mais liberado da pesquisa, foi cancelada. Chegamos a pensar em usar alguma plataforma de vídeo conferência (que tem sido a nossa "salvação" na quarentena para manter contatos com os amigos, com a família, com os orientandos e para dar continuidade ao trabalho possivel por esse meio), mas desistimos. Seria um duplo trabalho: gravar a entrevista nessas condições e depois transcrevê-la. Nesse meio tempo tive muitas dúvidas sobre a pertinência da entrevista nesse cenário desolador. Meu tempo, assim como o de muitas pessoas que estão em quarentena e confınadas em casa (há três semanas, desde 26 de março de 2020), sofreu um encurtamento drástico: 24 por 24 horas. Um dia de cada vez.

Adepta da mobilidade urbana, usuária do transporte público, nadadora há mais de trinta anos, orgulhosa de conciliar o trabalho intelectual com a prática diária de alguma atividade física, tive que inventar uma 
rotina de exercícios dentro de casa. Tive que me haver também com a "descoberta" dos riscos a que estou exposta pela idade, reforçados pelo casamento com um cardíaco. Todos os controles de onipotência, duramente desconstruídos ao longo de 10 anos de análise, voltaram à tona nesse momento.

Com isso, passo às perguntas e ao roteiro formulado por Eliana e Camila.

Heloisa, conte-nos sobre o seu percurso biográfico antes da chegada à universidade e a ida para São Paulo. Gostaríamos de saber mais sobre a sua infância em Belo Horizonte e, depois, em Brasília. 0 que motivou a mudança? A carreira do seu pai? E a sua mãe, o que fazia? Se der, por favor, fale um pouco sobre os seus avós paternos e os maternos.

Eu nasci em Belo Horizonte, em 1959, filha de pai universitário e mãe dona-de-casa. Aos quatro anos, em 1963, nos mudamos para Brasília. Meu pai, Hélio Pontes, ligado naquele momento à Faculdade de Ciências Econômicas da Universidade Federal de Minas Gerais, recebeu um convite de Darcy Ribeiro para se integrar ao corpo docente da então novíssima Universidade de Brasília, na qual ele era reitor. Moramos meu pai, minha mãe e meus dois irmãos mais novos, um deles ainda bebê - na superquadra 308. Em Brasília descobri a piscina, a liberdade do movimento, o carrinho de rolimã, a bicicleta, a cidade modernista de espaços imensos e céu exuberante. Mas pouco tempo depois de instalada e aclimatada, meu mundo infantil se partiu.

No dia 22 de dezembro de 1963, quando viajávamos de carro para passar o natal com a família paterna em Belo Horizonte, sofremos um acidente. Minha mãe, Alexandrova Mendes André, uma jovem de 29 anos, perdeu o controle do carro, pressionada por um motorista de caminhão, e o carro rolou abaixo da estrada. Ela morreu na hora. Meu pai quebrou as duas pernas e nós três, os filhos, saimos intactos. Fisicamente, bem entendido. Minha vida, claro, nunca mais foi a mesma. Posso dizer sem complacência que a infância acabou ali.

Quando voltei para Brasília, depois de uns dois meses de movimentação por casas diferentes, onde parentes mais próximos cuidavam de nós, enquanto meu pai se recuperava na casa da minha avó paterna - Maria Helena, minha referência decisiva, de amor e afeto incondicional - estranhei tudo. Eu sabia sem saber que não pertencia mais ao mundo dos meus coleguinhas de escola, sobretudo na hora da saída, quando as mães vinham buscá-los. Um dia, por uma confusão na agenda dos meus tios maternos que foram passar um tempo conosco para ajudar meu pai, não apareceu ninguém para nos buscar. Irmã mais velha, com cinco anos, fiquei sentadinha na escada com meus dois irmãos menores, acalmando-os enquanto um deles, aos prantos, chamava pelo pai.

Eu detestava o olhar de compaixão, muitas vezes misturado com vislumbres de perversão (vistos de hoje) que as pessoas nos dirigiam quando informados da nossa orfandade. Uma certa altivez da minha parte, embalada pela descoberta e pelo prazer da leitura que soltava a imaginação, se mesclava, de maneira confusa, ao sentimento de distância, de não pertencimento à vida meio açucarada da infância da classe média. Isso me levou ao estudo e ao desejo de outros mundos.

A morte da minha mãe e meses depois o golpe militar de 1964 (me lembro dos tanques circulando pela esplanada de Brasília) se somaram à situação insustentável 
na Universidade de Brasília. Com o exílio de Darcy e a destituição de Anísio Teixeira, então reitor, a ditadura se encarregou de nomear um reitor politicamente alinhado. Em outubro de 1965, Laerte Ramos de Carvalho solicitou o envio de tropas militares ao campus para conter a greve dos estudantes e demitiu 15 professores, entre eles meu pai. 0 corpo docente se rebelou e 223 dos 305 professores na época se demitiram.

Voltamos, então, para Belo Horizonte, e meu pai reassumiu o cargo de docente na UFMG, a mesma instituição que abrigaria Eunice Pontes, sua segunda mulher, com quem ele se casara quando ainda estávamos Brasília. Nesse período, Eunice estava fazendo o mestrado em Linguística - área na qual ela se notabilizou por sua produção arrojada sobre a estrutura e dinâmica do português falado.

Ter dois modelos tão contrastantes de mulher foi marcante na minha vida. Minha mãe, como disse antes, era dona-de-casa e não se profissionalizou. Com três filhos pequenos, ela se esmerava na vida doméstica, cozinhava bem, fazia vestidos lindos para mim, cuidava de nós e da casa. Ela conheceu meu pai quando ambos estudavam em Juiz de Fora no Grambery, um colégio metodista misto que tinha, na época, um internato para rapazes e moças. Meu avô materno, Manoel Mendes André, imigrante português que enriqueceu no Brasil e se ligou ao círculo cultivado de esquerda no Partido Comunista, havia permitido que minha mãe saísse de casa para estudar como uma forma de contornar os conflitos familiares.

Com a morte da minha avó materna, quando minha mãe tinha apenas dois anos, meu avô ficou viúvo com três filhos pequenos. Jovem, sem estabilidade financeira, ele contou com a ajuda dos parentes da família da sua mulher e com amigos para cui- dar dos filhos. Minha mãe só voltou a morar com seus dois irmãos mais velhos depois que meu avô se casou de novo. Saíram de Uberaba e foram morar em São Paulo. Mas se isso permitiu à minha mãe partilhar da companhia dos irmãos e da convivência com o pai, não impediu que os conflitos com a "madrasta" ganhassem intensidade incontornável. A saída para Juiz de Fora na companhia do irmão mais velho e o namoro com meu pai garantiram a ela uma vida mais feliz, selada com o casamento e o nascimento dos três filhos (meus dois irmãos mais novos e eu, a primogênita).

Autodidata e cultivado, meu avô materno, Mendes André, à medida que os recursos financeiros se avolumaram, passou a se interessar, a comprar e a colecionar pintura. Portinari, Segall e os pintores do Grupo Santa Helena faziam parte da sua coleção. Para o projeto da sua casa, construída quando os filhos já eram grandes, ele chamou o arquiteto Vilanova Artigas, que, como ele, fora ligado ao círculo do Partido Comunista. Essa casa concentrava o seu arrojo em matéria de gosto arquitetônico e a materialização de um projeto bem-sucedido de ascensão social. Ele tinha orgulho da casa figurar nos compêndios da arquitetura moderna.

Na época em que a casa ficou pronta, minha mãe já estava casada com meu pai e morava em Belo Horizonte. Com a nossa ida para Brasília, a casa modernista do meu avô fazia par, na minha imaginação, com a cidade modernista que eu amei tanto quando era criança e, uma vez mais, na adolescência.

Engajado, de esquerda e dominador, meu avô materno contrastava com o meu avô paterno, Pio Pontes, desembargador, mineiro, oriundo de uma família mestiça, homem ponderado, espírita, politicamente conservador, cuja mulher, Maria Helena Pontes, mi- 
nha avó mais que querida, era a luz, com a irradiação de um cometa, da família.

Encerro por aqui a digressão pela genealogia familiar, para voltar ao ponto que pode ter um interesse maior para a entrevista: os dois modelos contrastantes de mulher que marcaram a minha vida, pessoal e profissional. De um lado, minha mãe, Alexandrova (o nome, uma corruptela do russo, foi escolha do pai comunista) dona-de-casa. De outro, Eunice, uma das primeiras linguistas brasileiras, que jogou sua energia no trabalho e na carreira. Ela ampliaria a família com o nascimento de mais dois irmãos, mas não fez da casa a sua assinatura na vida, como fizera a minha mãe. Numa época em que as mulheres de classe média, quando casadas, viviam para a família, Eunice destoava. Sobretudo naquela Belo Horizonte, provinciana e opressiva, da minha infância.

As conversas em casa giravam em torno da universidade, da política, das brigas intermináveis de departamento. Meu pai, sempre sabido e conciliador, ponderava com Eunice. No departamento dela, na época a briga era entre linguistas e os professores de letras aferrados à camisa-de-força da gramática. Por isso, quando virei professora, em 1984, ainda no mestrado, primeiro na PUC e, no ano seguinte, na UNICAMP, não me chocaram os conflitos (inevitáveis) entre colegas que passam ao menos trintas anos de suas vidas trabalhando juntos.

Se essa dinâmica não me era estranha, mais complicado foi lidar com a internalização desse modo de vida familiar e universitário que me marcou para sempre. Quando menina, sentia falta de uma casa organizada, com pires e xícaras combinando e não desconjuntados como era na minha casa. Isso era particularmente complicado quando eu via o espanto de alguma coleguinha da escola primária com a "bagunça" da minha casa. A maioria delas estava acostumada com as mães em casa preparando e servindo lanche para as amiguinhas que iam às casas delas para brincar ou fazer os deveres da escola. Eunice estava sempre lendo, estudando, correndo contra o tempo para se inteirar da bibliografia, dos cursos, dos alunos.

E eu sonhando com uma casa impecável até que passei num exame concorridíssimo e entrei no Colégio de Aplicação da UFMG, que ficava quase ao lado da Faculdade de Filosofia e Ciências Humanas (mais conhecida por FAFICH). Eu tinha 10 anos quando passei no exame e onze quando ingressei nesse colégio. Foi uma libertação! Encontrei colegas vindos de famílias mais parecidas com a minha e pouco tempo depois fiz uma turma de amigos. Leila Diniz, cuja morte nos chocou, era a nossa musa e tudo que associava liberdade à contestação caia na nossa rede de interesses.

Com a transferência do colégio para o campus da UFMG na Pampulha, nos sentíamos quase uns universitários, embora estivéssemos ainda no primeiro grau. 0 carro do meu pai, uma vemaguet em estado deplorável, virou a sensação entre os meus amigos, na época descobrindo o cinema e experimentado roteiros e filminhos em super 8 .

Eu que, até então, vivia dos livros, declarei um dia em casa que não leria mais, pois estava vivendo! E dei por encerrada aquela conversa familiar sobre a bolsa do CNPq, que tanto me atormentava. Considerada pesquisadora paradigmática da área de linguística, Eunice, com apoio do meu pai, vivia dizendo que se eu não estudasse bastante, caso quisesse seguir a carreira universitária, não teria essa bolsa. Brinco que foi preciso muita análise para me decidir a pleitear essa bolsa...

No bem-bom da adolescência, com uma turma inseparável de amigos, meu pai re- 
cebeu um novo convite para voltar à Brasília, desta vez para trabalhar no Ministério da Educação, enquanto Eunice se transferiu para a Unb. Eu tinha 15 anos e, ao contrário de um dos meus irmãos que sofreu enormemente com a mudança (que atiçou o início da sua esquizofrenia), logo me aclimatei e passei a fruir a liberdade que a cidade oferecia. Rapidamente fiz novos amigos, me matriculei no que sobrou do então colégio de Aplicação, na sua versão paga e já depauperada do ponto de vista escolar, e passei a seguir o segundo grau numa concepção educacional chamada "ritmo próprio". Algo que só mais tarde vim a saber que é característico do supletivo. Para não me estender no assunto, basta dizer que eu recebia as apostilas das matérias, tirava as dúvidas eventuais com os professores, fazia os testes e seguia no meu ritmo. Como eu era rápida, um dia o diretor me chamou para dizer que naquele ritmo eu terminaria o segundo grau em um ano e não nos dois que ainda faltariam se eu estivesse numa escola normal. 0 aviso significou tomar providências práticas para me preparar e fazer o vestibular. Me matriculei num cursinho, à tarde, enquanto seguia com os testes de manhã no colégio. 0 cursinho não adiantou quase nada, pois o que eu sabia (de português, história, literatura, inglês e até geografia) era mais do que a média e o que eu não sabia (matemática e química, sobretudo) não iria aprender em tão pouco tempo.

Me inscrevi no vestibular para ciências sociais, que pesou mais na balança que psicologia, estudei o que estava ao meu alcance, indo e vindo da casa de uma amiga, filha do sociólogo Fernando Correia Dias, fiz as provas e passei!! Foi um acontecimento. Eu tinha 16 anos e estava em guerra com a família e especialmente com a Eunice. Vinda de outra experiência de classe, ela não me poupava das frases ferinas. Uma delas: "vo- cê não estuda o suficiente porque tem tudo na vida e não tem com que se preocupar", e coisas do gênero. Parêntesis: hoje temos uma relação muito boa e afetuosa e eu tenho grande admiração pela história de vida e pela inteligência dela: uma lutadora como são os nossos melhores alunos de origem social humilde, integrantes da primeira geração da família a cursar a universidade.

E como foi a sua a trajetória universitária? 0 que influenciou a opção pelas ciências sociais e como foi a entrada na UNB e o ingresso na UNICAMP?

Ingressei na Universidade de Brasília em 1976. Lá conheci um monte de gente incrivel, tive professores notáveis (como Fernando Corrêa Dias, que me deu 10,0 na minha primeira prova de sociologia), me engajei no movimento estudantil e na luta contra a ditadura. No ano seguinte, participei de uma greve longuíssima, na qual ocupamos a universidade, mesmo com a ameaça da entrada da polícia. 0 semestre foi cancelado, meu namorado na época foi expulso da universidade e quando as aulas recomeçaram a polícia e os cães foram convocados pelas forças repressivas para "garantir" as aulas. Horrorizada com a situação, sabia que poderia contar com a cumplicidade do meu pai, para deixar a UNB e, assim, sair de casa.

Eu queria vir para São Paulo para estudar na USP, mas estávamos em julho de 1977 e não tinha vestibular no meio do ano. Em compensação, na UNICAMP, que, segundo meu pai, era uma ótima e jovem universidade, tinha um exame, aplicado antes do início do segundo semestre, para alunos que queriam se transferir de universidade. Nunca tinha ido à Campinas, me inscrevei, passei e me mudei, no melhor estilo "sem 
lenço e sem documento". A primeira carteira de identidade que tive foi tirada em Campinas para que eu pudesse me matricular, já que a certidão de nascimento, que eu levara comigo, junto com uma mala e meu travesseiro, não era suficiente. Vim de Brasília para Campinas, sozinha, de ônibus com meus pertences e fui morar numa república onde residia um primo, que estava cursando economia na UNICAMP. Acho que fui a décima moradora dessa república. Logo depois vieram meu namorado e uma amiga em comum de Brasília. E foi assim que ingressei na UNICAMP: para dar continuidade à graduação em ciências sociais, sair de casa, experimentar uma vida diversa daquela que eu tivera até então na família. Seis meses depois, já me sentia completamente aclimatada. Não na cidade, que me parecia um tanto hostil, mas na UNICAMP.

Seis meses depois, meu pai, meus quatro irmãos e Eunice se mudaram para os Estados Unidos. Foram de Brasília para Washington, onde moraram por quase três anos. Meu pai havia sido convidado para trabalhar no Banco Mundial, no setor ligado à educação, e Eunice aproveitou a oportunidade para fazer um pós-doutorado.

Assim, de uma hora para outra, vivia a experiência inédita para a maioria dos meus colegas da UNICAMP de morar num continente e minha família em outro, dona da minha vida, aprendendo a bancar as minhas escolhas, fazendo amigos, entrando em contato com um monte de coisas interessantes e desafiantes. Entre elas, a experiência de dividir as tarefas domésticas nas várias casas em que morei com outros estudantes ao longo da graduação, entre 1977 e 1980, e o ambiente intelectual arejado e es- timulante que marcava o debate, as disciplinas, as relações entre os alunos e os professores no Instituto de Filosofia e Ciências Sociais na UNICAMP. Outro acontecimento importante foi a participação no Coletivo de Mulheres e o encontro, decisivo na minha vida, com Bibia (Maria Filomena Gregori). Amiga de todas as horas, fomos por quase trinta anos colegas no Departamento de Antropologia da UNICAMP. Nesse período virei feminista a partir de uma experiência singular e intergeracional.

Recorro aqui à memória da Bibia sobre o período (exposta no dossiê que organizamos juntas em 2018, em homenagem à antropóloga Mariza Corrêa ${ }^{2}$, minha orientadora no mestrado e referência importantíssima para nós duas), pois ela sintetiza com riqueza e delicadeza a nossa vivência do feminismo, na época em que fazíamos a graduação e dividíamos a mesma casa, as leituras, o curso de ciências sociais e a pesquisa com a qual nos tornamos antropólogas.

Nesse período, marcado pelo declínio da ditadura militar e pela reorganização da sociedade civil, além de intensa participação em eventos pré-abertura política e passeatas, ingressamos no Coletivo Feminista de Campinas. Um grupo formado por estudantes e professoras jovens como Mariza Corrêa, Verena Stolke e Jeanne Marie Gagnebin, que apresentaram - relembra Bibia - "a nós, as alunas, a obra de Michel Foucault, de antropólogas feministas como Michelle Rosaldo, Louise Lamphere, Sherry Ortner e historiadoras como Sheila Rowbothan e sua análise arguta da trajetória de algumas inglesas que passaram da New Left para os grupos feministas, ainda no final dos anos 60. Mais do que um grupo de estudos, tratava-se de uma

2. Cf. PONTES, Heloisa e GREGORI, Maria Filomena. "Dossiê Mariza Corrêa: laços, memória e escritos”. Cadernos Pagu (54), 2018. 
alternativa de ativismo coletivo e, sobretudo, pessoal (...). Nós estávamos fascinadas pela questão do feminismo tanto em termos teóricos como políticos e a animação também se devia ao convívio entre mulheres interessantes e de diferentes gerações". Nas reuniões semanais, cada semana na casa de uma das participantes, "sentadas nas almofadas coloridas e com as costas apoiadas nos panos indianos pendurados nas paredes, circulava muito afeto, risos contidos e outros abertos quando, ao tentarmos discutir conceitualmente os limites do tratamento universalista atribuído à 'condição feminina' (nosso ímpeto crítico sempre esteve em evidência), tratávamos de descrever episódios vividos nas famílias de origem, ou as nossas primeiras histórias amorosas e sexuais. Menos do que identificar uma opressão universal ou a denúncia abstrata do patriarcalismo, fazíamos uma espécie de terapia radical, com espaço e solidariedade para falar de experiências de aborto e de fantasias sexuais, transitando do difícil ao divertido sem os rigores da vida acadêmica ou os maniqueísmos da vida política”.

0 seu mestrado foi realizado logo na sequência, entre 1981-86, também na UNICAMP. 0 que a motivou a escolher a Antropologia e a trabalhar com questões de gênero e com o feminismo, na dissertação "Do palco aos bastidores: o SOS-Mulher e as práticas feministas contemporâneas"? Como se deu a escolha de Mariza Corrêa como orientadora?

Para mim e para todas que participaram do Coletivo Feminista, essa experiência, a um só tempo afetiva, intelectual e política, acabou nos levando para os estudos de gênero. Mas a decisão de pesquisar o movimento feminista, com foco no SOS-Mulher (criado como uma frente feminista para lidar com a violência de gênero), só aconteceu no final da graduação, em 1980. Dividida entre prestar o mestrado na antropologia ou na teoria literária, pedi ao professor Haquira Osaka que lesse um projetinho que eu tinha escrito, enquanto fazia um de seus cursos na área de linguística. Amigo de José Miguel Wisnik, Haquira, além de excelente professor, cozinhava divinamente e dividia a casa com Ana Fonseca, minha colega na graduação, que também integrava do Coletivo Feminista. Ex-presa política, inteligente, conversadora, viva, Ana me "maternava" na sua casa e nos cursos que fizemos juntas na graduação. No primeiro seminário que dei como aluna, fui tomada por um nervosismo tão intenso que achei que não conseguiria falar. Ana, que fazia parte do grupo expositor, não apenas me acalmou, como escolheu um lugar estratégico na mesa que usamos para apoiar o material e, sem que as outras pessoas vissem, segurou a minha mão enquanto eu falava. Ganhamos 10,0 do professor pelo desempenho.

Voltando a ela e ao Haquira. Ambos me acolhiam sempre que eu precisava de uma casa segura, afetiva, animada por conversas incríveis sobre política, cultura e literatura. 0 que as séries que povoam e inundam o Netflix são para as gerações mais novas (e não só!), a literatura era para nós no período. Não tínhamos televisão. Cinema, teatro e shows dependiam do deslocamento para São Paulo - Campinas, apesar de abrigar a UNICAMP e a PUC, não era uma cidade com destaque cultural. Telefone era artigo

3. Cf. Maria Filomena Gregori "Contextos de formação: a importância de Mariza Corrêa para uma geração”, Cadernos Pagu, nº 54, Campinas, 2018, Epub 29-Nov-2018. 
de luxo. A sociabilidade universitária se nutria dos encontros presenciais e, no meu caso e de outros amigos, a literatura ocupava um lugar especial nas nossas conversas e no aprendizado da nossa educação sentimental.

Voltando ao projetinho que pedi a Haquira para ler, intitulado "Literatura no feminino". Ele foi escrito em meio à empolgação com a leitura de Orlando, de Virgínia Woolf - que confirmava mais uma vez, para mim, o vigor com que a literatura descortina dimensões ao mesmo tempo sutis e poderosas da vida social, tornando pálidas muitas das leituras feitas no curso de ciências sociais. A ideia era analisar a poesia de Adélia Prado à luz do debate que se travava na época sobre a existência ou não de uma escrita feminina. Desencadeado pela releitura de Clarice Lispector e pela entrada na cena política do final dos anos de 1970, dos então chamados novos movimentos sociais, entre eles o feminista, tal debate desaguava na discussão sobre as construções sociais do feminino e do masculino (gênero ainda não era um termo utilizado) e, por tabela e para resumir uma discussão interessante, na antropologia.

Afinadíssimo com os debates que ecoavam por todos os lados, Haquira Osakabe leu a minha proposta e sugeriu que eu trouxesse a experiência dos movimentos sociais para o centro da cena, usasse a literatura como pano de fundo e desse continuidade ao trabalho no mestrado. Na antropologia e não na teoria literária. Diante do que estava sendo produzido por Foucault e Lévi-Strauss, para citar dois dos pensadores mais importantes, e por vários antropólogos situados aqui e alhures, Haquira insis- tiu que eu teria muito mais a aprender com a antropologia do que com os estudos literários. Delicada maneira de dizer que eu não fora talhada para eles e de valorizar o que ele vislumbrava como um potencial no meu perfil. Encerrado o dilema, fui virando cientista social, sem abandonar o fascínio pela literatura e o desejo de me mover por entre as frestas de definições disciplinares estritas. Claro que não escapei às pressões advindas dessa pretensão - juvenil para muitos, inconsequente para outros, acertada, para alguns.

No programa de mestrado da UNICAMP, encontrei um ambiente intelectual estimulante, professores empenhados, colegas inquietos, uma turma de referência, uma orientadora vigorosa, Mariza Corrêa. Antropóloga potente e a um só tempo sutil, avessa ao exibicionismo mundano, Mariza me ensinou que a atividade intelectual vigorosa passa sempre pela escrita. Sua obra mostra o quanto o arrimo da ideia do real como construção complexa de sentidos - permeada por dispositivos de poder - só se sustenta com uma atenção redobrada na narrativa e na escrita. A paixão de pensar e o encanto pela literatura fomentaram nela uma dicção singular. Era pela escrita - e não só pelo conteúdo de seus argumentos - que ela punha a imaginação a serviço do discernimento rigoroso, inseparável do alcance de suas análises ${ }^{4}$.

Tendo começado a carreira como antropóloga sob a orientação de Mariza (fui sua primeira orientanda) e com uma pesquisa de campo sobre o movimento feminista, do qual participei inicialmente como militante, me vi às voltas no decorrer da pesqui-

4. Para uma visão mais ampla da importância de Mariza Corrêa e de sua obra para a antropologia brasileira, ver o "Dossiê Mariza Corrêa: laços, memória e escritos”, que organizei com Maria Filomena Gregori, publicado nos Cadernos Pagu (54), 2018. 
sa com os problemas postos pela relação sujeito e objeto - termo usado na época (hoje todos viraram sujeitos e interlocutores) e com as dificuldades para traduzi-los em chave etnográfica. Para levar adiante a pesquisa fui me distanciado da militância, sob pena de não fazer nem antropologia nem política. No movimento feminista passei a ser vista como uma militante pela "metade", enquanto na academia, corria o risco de não ser reconhecida como pesquisadora por estar comprometida demais com o meu objeto. Para sair do impasse em que me vi colocada - o de estar em lugar algum, que é o mesmo que estar no pior dos mundos - tive que objetivar a minha própria experiência em conjunto com a experiência das militantes que eu pesquisava. Nesse esforço de objetivação e no compasso analítico que lhe confere forma e direção, fui me distanciando dos pressupostos e das motivações iniciais que me levaram ao feminismo. E fui buscando uma forma expressiva de apresentar a etnografia. A "solução" dessa busca veio, como quase tudo na vida, da uma mistura de acaso e procura reiterada daquilo que nos "põe de pé". No meu caso, a literatura, e neste caso específico, da leitura de um romance de grande sucesso na época, $O$ nome da rosa, de Umberto Eco.

Por um desses mecanismos óbvios de condensação e deslocamento, comecei a achar que o meu desafio com a escrita etnográfica era parecido com aquele enfrentado por dois personagens notáveis do livro: o frei Guilherme de Baskerville e o noviço beneditino, Adso de Melk. No findar do ano de 1327, ambos se viram envolvidos em uma trama intrigante, motivada por estranhos e complicados acontecimentos ocorridos nu- ma abadia italiana, concentrados na morte misteriosa de cinco religiosos seguidores da ordem beneditina. Guilherme foi designado pelo abade para esclarecer o mistério, na companhia de Adso, seu discípulo e escrivão. Com argúcia os dois vão recompondo os fios da trama e descobrem que as mortes tinham a ver com algo que se passava dentro da biblioteca da abadia. Ali onde se depositavam os saberes mais cobiçados da época, encontravam-se também as pistas que Guilherme e Adso estavam prestes a decifrar quando se deram conta que a biblioteca tinha sido construída sob a forma enigmática de um labirinto.

Comentando o funcionamento de uma máquina que eles deveriam utilizar para se orientar na biblioteca e não se perderem no labirinto, Guilherme de Baskerville interpela Adso: "Se a máquina funciona seja dentro, seja fora da biblioteca por que não deveria ser assim com a nossa cabeça”. Ao que Adso retruca: "A nossa cabeça? Claro que ela funciona também, e de fora sabemos muito bem qual é a orientação do edifício! Mas é quando estamos dentro que não compreendemos mais nada!”. "Justamente”, disse Guilherme, "Pensar na máquina induziu-me a pensar nas leis naturais e nas leis do nosso pensamento. Eis o ponto: precisamos encontrar por fora um modo de descrever o edifício [a biblioteca] como ele é por dentro" 5 .

Elementar, meu caro Watson! Ali estava a solução para o meu dilema: encontrar por fora um modo de descrever o movimento feminista - e, em especial, o grupo sobre o qual fiz exaustiva etnografia - tal como ele era por dentro. Do palco aos bastidores: o SOS-Mulher e as práticas feminis-

5. Trechos extraídos do romance de Umberto Eco, O nome da rosa, Rio de Janeiro, Nova Fronteira, 1983, p. 250-51. 
tas contemporâneas, minha dissertação de mestrado e meu primeiro trabalho de fôlego, é uma tentativa de analisar o perfil e a ideologia do movimento feminista paulista, a composição de seu quadro de militantes, sua dinâmica e trajetória no cenário político brasileiro. Analiso também as representações e as formulações feministas sobre a então chamada condição feminina e suas implicações nas práticas políticas e culturais do movimento. Os dois primeiros capítulos apresentam uma análise do movimento feminista; os dois últimos constituem a etnografia do grupo SOS-Mulher. Situo o movimento feminista no campo político-ideológico definido pelos movimentos sociais da época (tidos como de natureza "libertária" ou "alternativa") e no campo da produção analítica interessada em compreender a sua constituição e trajetória específicas. Reconstruo a história do feminismo em São Paulo, dos grupos que o integravam e dos principais eventos que realizaram na década de 1970 e início dos anos de 1980.

Talvez a maior contribuição da dissertação esteja no segundo capítulo, no qual procuro mostrar que a análise do movimento feminista não pode se ater apenas à sua organização formal (recusa às lideranças, ao profissionalismo, negação do sistema de representação, vivência do coletivismo como forma privilegiada de organização que fundamenta a ideologia dos movimentos sociais de tipo "alternativo"). Isso é insuficiente para explicar a sua dinâmica interna, marcada por um processo ininterrupto de oposições e segmentações entre os grupos feministas que integravam o movimento. Tais grupos, ao mesmo tempo em que lutavam pelo reconhecimento da condição específica das mulheres, pareciam se organizar para assinalar diferenças internas entre eles. A identidade política dos grupos femi- nistas ganhava, assim, uma dimensão claramente contrastiva. Enquanto espaços de aprendizado da militância feminista, esses grupos eram um campo de iniciação e conversão ao universo cultural, existencial e comportamental do feminismo, realizada com o auxílio de uma pedagogia feminista.

Heloisa, podes nos contar um pouco sobre o que estava acontecendo na sua vida pessoal e profissional enquanto você escrevia a dissertação? Quando ela foi defendida você já era professora na UNICAMP?

Defendi a dissertação em novembro de 1986, quatro meses depois do nascimento do meu filho, João. Aliás, pus o ponto final na dissertação uma semana antes do nascimento dele. Naquele momento, era aluna e professora. Minha primeira experiência como docente foi em 1984, no terceiro ano do mestrado, quando ingressei na PUC de São Paulo, num concurso para professor substituto. Lá conheci meu segundo marido e pai do meu único filho, o também antropólogo Guilherme Simões Gomes. Um ano depois, em 1985, fui aprovada numa seleção interna do então conjunto de antropologia (ainda não era um departamento) e me tornei professora da UNICAMP. Imaginem: naquela época ainda era possível fazer o mestrado em cinco anos e ingressar na carreira docente da UNICAMP sem ter o mestrado defendido! Junto comigo, foram selecionados mais três colegas da minha turma de mestrado: Nestor Perlonger, Lilia Schwarcz e Nádia Farage. Por um bom tempo fomos os professores mais jovens do Departamento. Eu tinha 26 anos e de maneira meio abrupta deixava de ser aluna para me tornar colega dos meus professores: Antônio Augusto Arantes, Peter Fry, Mauro Almeida, Manuela Car- 
neiro da Cunha, Alba Zaluar, Guita Debert, Suely Kofes, Mariza Corrêa, Carlos Brandão, entre outros. Verena Stolcke, tão importante na minha graduação, já havia retornado à Espanha quando virei professora.

Concluído o mestrado em 1986, demorei mais quatro anos para ingressar no doutorado. Tal espaçamento e hesitação ainda eram possíveis naquela época. E quando decidi o tema do doutorado, já estava inteiramente envolvida numa nova divisão: professora de antropologia, fui cursar o doutorado na sociologia e na Universidade de São Paulo. A ligação entre a antropologia e a sociologia na área que escolhi, a sociologia da cultura, guiada pela orientação segura e firme da profa. Maria Arminda do Nascimento Arruda, era nítida para mim. Mas obscura e até mesmo "suspeita" para vários antropólogos e colegas meus, que não entendiam o que os meus temas e objetos tinham a ver com essa disciplina. Intelectuais, atrizes, ensaístas, escritores, dramaturgos - o que estes sujeitos teriam a ver com a antropologia?

Ciência das formas e dos fundamentos simbólicos da vida social, a antropologia, a meu ver, não pode se furtar à análise do mundo da arte e dos campos especializados de produção simbólica. Se esta é uma resposta possível para a inclusão da vida intelectual, do "mundo da arte" e de seus praticantes, no âmbito dos objetos antropológicos, existem outras, delineadas ao sabor do acaso e dos encontros.

Heloisa, fale um pouco mais sobre essa dimensão do acaso na sua trajetória. Entre o mestrado e o doutorado, você atuou no projeto "História das Ciências Sociais" e, em seguida, no projeto "História Social das Artes Plásticas no Brasil”. Ambos coordenados pelo sociólogo
Sergio Miceli, desenvolvidos no IDESP (Instituto de Estudos Econômicos e Sociais de São Paulo) e com financiamento da FINEP. Sabemos que eles foram feitos em equipe com vários pesquisadores. Essa característica, nos parece, contribuiu para fortalecer o elo entre USP e UNICAMP. E também para o desenvolvimento de certa forma de fazer análise da cultura e dos intelectuais, para as quais sua atuação foi fundamental. Ali, você também mobilizou as suas redes ligadas à UNICAMP, muitas das quais já iniciadas no debate das questões de gênero. Como se deu a reunião desses pesquisadores, a escolha e a divisão do trabalho entre vocês?

Em parte pela minha insegurança com os resultados alcançados na dissertação, em parte pelos dilemas vividos ao escrever a etnografia e pelos encontros profissionais, decisivos e inesperados, migrei de área e de objeto. Feminismo não era um assunto de relevo na hierarquia dos objetos prestigiados na época. Não publiquei o mestrado. Tampouco cogitei de enviálo para apreciação de alguma editora. Nos anos de 1980, a importância e o peso das revistas acadêmicas ainda eram pequenos. Não se tinha a prática de escrever artigos como hoje. 0 que todos queriam, mas só alguns conseguiam, era publicar um livro. E isso dependia não só do mérito, mas do capital de relações que os alunos tinham (ou não) e podiam mobilizar para que o trabalho chegasse, normalmente por indicação, aos editores. Não era o meu caso.

No lugar de dar continuidade ao estudo dos movimentos sociais e às questões postas pela relação entre cultura, poder e política em chave antropológica, comecei a enveredar pela sociologia da vida intelectual 
e da cultura. De início, pensei em contextualizar a pesquisa feita no mestrado no âmbito da história intelectual e institucional da antropologia brasileira, com o propósito de entender melhor o que se chamava na época por “antropologia na cidade”, área na qual se inscreviam objetos muito variados, de movimentos sociais a bailes funks. Em 1987, redigi um novo projeto com a finalidade de investigar essa vertente da disciplina e seu desenvolvimento no Brasil. Para fazer isso, iniciaria pelo levantamento das dissertações de mestrado e das teses de doutorado em antropologia, arroladas na categoria de "urbanas" ou de "antropologia na cidade”, defendidas nos principais centros de pós-graduação em antropologia do país. 0 objetivo desse levantamento era duplo: analisar os modos de constituição desse campo temático e seus desdobramentos teórico-metodológicos; investigar de que maneira esses centros de pós-graduação tinham contribuído para a legitimidade e a institucionalização de certos temas e objetos de estudo, em detrimento de outros. Tinha a intenção de fazer uma "etnografia" dessa produção, com o intuito de discutir os paradigmas teóricos que a sustentavam. Isso exigiria não apenas a leitura sistemática das dissertações e teses na área, como também um levantamento e análise das fontes bibliográficas utilizadas por elas.

Quando redigi o projeto e o encaminhei para o Departamento de Antropologia da UNICAMP em abril de 1987, justifıquei a sua relevância no sentido de que a pesquisa poderia fornecer um material analítico interessante para um projeto mais amplo sobre a história das ciências sociais no Brasil, que estava sendo desenvolvido na época, no IDESP (Instituto de Estudos Econômicos e Sociais de São Paulo), por uma equipe de cientistas sociais e historiadores, sob a coor- denação de Sergio Miceli. Um dos integrantes dessa equipe, o cientista político Fernando Limongi, soube por intermédio de Fernanda Peixoto (então Massi e aluna do mestrado em antropologia da UNICAMP) que eu estava interessada nessa história das ciências sociais. A notícia foi parar em São Paulo (não havia e-mail na época) no momento em que o projeto estava se ampliando e a equipe precisava de novos pesquisadores. Recebi, então, um telefonema de Limongi me convidando para um seminário do grupo e uma entrevista com Miceli.

A entrevista foi rápida. Expus os objetivos da minha pesquisa e as razões do meu interesse no projeto. Como resposta, recebi dois enormes relatórios produzidos pela equipe, um prazo de uma semana para lê-los e para definir um objeto de investigação pertinente com o quadro de temáticas e problemas abarcados pelo projeto. Com a ressalva clara de que a pesquisa sobre a história das ciências sociais que estava sendo feita naquele momento centrava-se no período de 1930 a 1960. Portanto, ainda que os anos pós-1968 fizesse parte do escopo de investigação proposto pela equipe, eles só seriam contemplados depois. Redirecionei então o meu projeto inicial e integrei-me, em 1987, à equipe, composta por pesquisadores experientes e por jovens em início de carreira, como era o meu caso na época, com formações distintas (ciência política, antropologia, sociologia e história). Ao longo de três anos, a equipe trabalhou com objetos variados, alinhavados por uma perspectiva teórico-metodológica comum: fazer uma sociologia intelectual e uma história social do campo das ciências sociais, de seu processo de institucionalização, de seus atores e de sua produção. Cada membro da equipe se responsabilizava por um objeto e por uma parte dessa histó- 
ria, com o compromisso de apresentar, para o grupo, os textos produzidos com os resultados da pesquisa.

Esta experiência profissional e intelectual foi decisiva na minha formação acadêmica e no meu treinamento como pesquisadora. Muito do meu entendimento a respeito do trabalho intelectual, da elaboração dos argumentos analíticos necessários para levar adiante todo e qualquer projeto de pesquisa, do aprendizado com as fontes, em termos das perguntas que precisam ser feitas para o desvendamento das marcas sociais inscritas no material e na documentação que utilizamos, deve-se à experiência que tive no IDESP. Os integrantes da equipe, situados em momentos distintos da carreira acadêmica, tinham seus textos lidos, criticados e discutidos por todos. Esta diversidade interna se expressava na elaboração, no alcance analítico dos textos, no repertório de questões e sugestões de cada um.

Trabalhar em conjunto com pesquisadores sêniores como Maria Hermínia Tavares de Almeida, Fernando Novais, Maria Arminda do Nascimento Arruda, Mariza Corrêa e Sérgio Miceli, ao lado de pesquisadores júniores, como eram, na época, o meu caso e os de Silvana Rubino, Glória Bonelli, Fernanda Peixoto, Fernando Limongi, Paul Freston e Lilia Schwarcz - todos nós no começo da carreira - nucleados por um trabalho comum de pesquisa e reflexão, foi uma experiência decisiva para a minha compreensão do significado, do tempo de maturação, dos requisitos e recursos intelectuais, biográficos e sociais que envolvem, modelam e condicionam o trabalho intelectual.

Como membro da equipe, desenvolvi e conclui três projetos de pesquisa, cujos resultados foram publicados sob a forma de artigos, capítulos de livros e guia de referência. 0 primeiro deles centrou-se na aná- lise comparativa das três coleções de assuntos brasileiros mais importantes editadas no país, nas décadas de 1930 a 1960: Brasiliana, Documentos Brasileiros e Biblioteca Histórica Brasileira. Enquanto um dos espaços privilegiados para a veiculação do pensamento social da época, essas coleções, juntamente com os editores e as editoras que as publicaram (Nacional, José Olympio e Martins, respectivamente), foram analisadas como um dos "requisitos institucionais" que moldaram o perfil do campo intelectual da época. Fontes de prestígio para os editores e as editoras, lugar de consagração para os autores editados, elas oferecem uma chave para a compreensão do universo cultural e intelectual do período.

A análise dessas coleções evidenciou, entre outras coisas, o peso dos cientistas sociais estrangeiros no conjunto dos trabalhos sociológicos e antropológicos sobre o Brasil. Diante disso, dei início à segunda pesquisa no âmbito do projeto sobre a história das ciências sociais. Esta consistiu na análise da produção de cientistas sociais e historiadores estrangeiros sobre o Brasil, editada aqui, a partir dos anos de 1930, sob a forma de livros. Usei o mercado editorial como uma porta de entrada para entender as relações intelectuais e acadêmicas, configuradas no jogo triangular entre o Brasil, a Europa e os Estados Unidos. A perspectiva analítica que balizou a leitura desse material me permitiu fazer uma espécie de "genealogia" dos estrangeiros, em termos de sua inserção e percepção do país, numa cadeia onde os viajantes, os africanistas, os americanistas e, por fim, os brasilianistas, aparecem uns como antepassados dos outros. Permitiu-me também enxergar descontinuidades entre eles, deflagradas por mudanças internas nas ciências sociais brasileiras e por alterações nas condições de produção de saber dos es- 
trangeiros (e, portanto, dos "mapas" do Brasil que eles criaram) em seus países de origem. Como consequência, alteraram-se as relações acadêmicas e institucionais entre a comunidade nacional de cientistas sociais e historiadores e suas congêneres europeias e norte-americanas.

Por fim, a terceira pesquisa que eu iria fazer não foi adiante. Só tenho o registro dela no projeto "Relações intelectuais e acadêmicas entre o Brasil e a França, no campo das ciências sociais (1950-1990)". Escrito em janeiro de 1990, com a finalidade de ingressar no doutorado em sociologia da Universidade de São Paulo e, assim, iniciar uma pesquisa de maior fôlego sobre o perfil, o impacto e as condições de produção das relações intelectuais e acadêmicas entre o Brasil e a França, no conjunto específico das ciências sociais, o projeto previa um estágio de um ano em Paris. Admitida no doutorado em março de 1990, passei o primeiro semestre lendo tudo que podia e o tempo me permitia (pois fazia o doutorado e dava aula na UNICAMP). Os resultados imediatos dessas leituras e da imersão na área da sociologia da cultura apareceram nos artigos que publiquei na época e ganharam corpo na elaboração do meu projeto de tese, orientado pela profa. Maria Arminda do Nascimento Arruda, sobre o Grupo Clima no sistema cultura paulista

\section{E como foi a escolha da Maria Arminda para ser sua orientadora?}

Como disse antes, Maria Arminda era uma das integrantes do projeto da História das Ciências Sociais. Quando a conheci, fiquei fascinada pela ousadia que ela tinha no modo de se vestir, tão diferente do modo habitual nas ciências sociais. Seus sapatos de saltos altíssimos, a maquiagem, o pen- teado dos cabelos, tudo isso produzia um efeito notável, ampliado pela inteligência, pelo gosto pela literatura, pela capacidade argumentativa, pela firmeza com que conduzia o trabalho. Um ano depois de conhecê-la, ela ingressou no Departamento de Sociologia onde eu queria fazer o doutorado. Fui sua primeira orientanda. Aliás, minhas duas orientadoras, Mariza e Maria Arminda, eram jovens doutoras quando as escolhi para me orientar. Um gesto que teve um tanto de ousadia, pois elas não faziam parte (ainda) do “panteão" dos orientadores cobiçados. Na USP e naquele momento, isso era especialmente visível. Os alunos, por um desses mecanismos previsíveis de busca de reconhecimento e de autoria por procuração, costumavam medir a sua importância pela importância, real ou atribuída, de seus orientadores.

Quando Maria Arminda começou a me orientar, eu já estava separada do meu segundo marido. Meu filho tinha três anos, fazíamos guarda compartilhada e eu estava namorando Sergio Miceli, com quem estou casada há trinta anos. A experiência de formar uma nova família, com filhos de casamentos diversos, foi fascinante, conflituosa, desafiante e também bastante prazerosa. Ela me obrigou a rever a minha história familiar. Aquilo que eu tinha vivido com enorme conflito com a Eunice, a quem eu chamava de mãe, por recusar o termo madrasta e todo o imaginário que ronda essa figura ambígua, desdobrava-se na posição que eu passei a ocupar com os filhos do meu marido. Assim, ao mudar de "posição" pude entender melhor o que se passou na minha família. E, com isso, aprendi a lidar melhor com os conflitos inevitáveis nas famílias "reconstituídas", não pela morte de um dos cônjuges, mas pela separação e novo casamento em meio à guarda compartilha- 
da de filhos de casamentos anteriores. Para não pessoalizar demais essa entrevista, vou "pular" essa parte.

Como surgiu o tema do seu doutorado e o lugar que a figura da Gilda de Mello e Souza - a única mulher do Grupo Clima que conseguiu "fazer um nome" - ocupa na sua tese? Em que medida o seu doutorado se aproxima e se afasta do que você fez no mestrado?

Já virou um truísmo a ideia de que toda e qualquer reconstrução de um percurso não escapa à ilusão biográfica. A minha tampouco. Quando comecei a carreira acadêmica escolhi o feminismo como assunto porque estava siderada pela análise da microfísica do poder, pelo alcance do pressuposto de que o "poder se exerce mais que se possui” ${ }^{6}$ - aprendido com Foucault - e por sua reverberação no repertório dos movimentos sociais que punham em questão o problema da representação política. Ao aliar a etnografia à apreensão dos novos sujeitos políticos, a antropologia abria uma trilha inovadora de reflexão e me permitia tomar como objeto uma experiência social que era a minha e de muitas mulheres da minha geração. 0 embaço que isso criou me levou, como disse antes, a mudar de assunto depois do mestrado. Deixei de lado a cena pública e os bastidores do movimento feminista e enveredei pela história social da cultura e pela sociologia dos intelectuais.

Nessa seara busquei entender as condições e as constrições que enredam o trabalho intelectual (e artístico) e tornam possível (ou inviabilizam) a construção de uma voz autoral - mescla de assinatura, nome pró- prio, poder de agregação e de irradiação. No doutorado, busquei analisar essas dimensões com o auxílio do contraste entre Florestan Fernandes e os integrantes mais expressivos do Grupo Clima - e destes entre si. Esse recurso me permitiu aquilatar a espessura dos constrangimentos de classe e de gênero na montagem de um sistema intelectual marcado pela inovação reflexiva e pela permanência de relações de poder, que se exercem para além da vontade ou da consciência dos sujeitos envolvidos por elas.

Advém daí o meu interesse pela trajetória e pela obra de Gilda de Mello e Souza. Ela tinha 31 anos quando escreveu $A$ moda no século XIX: ensaio de sociologia estética. Apresentado em 1950 como tese de doutorado, sob a orientação de Roger Bastide (de quem ela era assistente na cadeira de sociologia I). A moda ganhou nesse trabalho um tratamento estético e sociológico inovador e sofisticado. Mas quando a tese foi defendida na então Faculdade de Filosofia, Ciências e Letras da USP, ela destoava da sociologia dominante na época. A começar pela forma de exposição do trabalho. Concebido como um ensaio de sociologia estética, o tema da tese de Gilda foi considerado, à boca pequena, fútil. Coisa de mulher. Na hierarquia acadêmica e científica da época, que presidia tanto a escolha dos objetos de estudo quanto a forma de exposição e explicação dos mesmos, ela constituiu "uma espécie de desvio em relação às normas predominantes". "Profana" e "plebeia", a moda, na escala de valor e legitimidade atribuídos por esse sistema classificatório, encontrava-se em uma posição diametralmente oposta ao tema da guerra, que Florestan Fernandes escolhera para a sua

6. Cf. Michel Foucault, Surveiller et punir, Paris, Gallimard, 1975.

7. Cf. Gilda de Mello e Souza, O espirito das roupas, São Paulo, Companhia das Letras, 1987, p.7. 
tese de doutorado, atividade masculina por excelência, "sagrada" e "nobre”.

Mais que qualquer outro assistente da Faculdade de Filosofia no período, Florestan concentrava a "voltagem" máxima de virtualidades na absorção do padrão de trabalho, da linguagem especializada e do rigor metodológico, introduzidos pelos professores estrangeiros. Por não ter os trunfos sociais e culturais de seus colegas, Florestan converteu a carreira no único meio possivel para angariar prestígio intelectual e se afirmar socialmente. E fez da guerra entre os Tupinambás - assunto da sua brilhante tese de doutorado - o "instrumento" e o "passaporte" para conquistar uma posição mais sólida na Universidade de São Paulo. Com a volta de Bastide para a França, em 1954, Florestan se tornou o "herdeiro" da cadeira onde Gilda trabalhara até então como assistente, e fez dela uma "instituição dentro da instituição”, conhecida por escola paulista de sociologia.

Florestan Fernandes e Gilda de Mello e Souza me permitiram entender melhor a força dos condicionantes e dos constrangimentos sociais na modelagem do trabalho intelectual. Gênero e classe incrustados em trajetórias particulares, inseparáveis das relações de poder que conformam os campos de produção simbólica.

Meu interesse pela obra e trajetória de Gilda se estendeu para além do doutorado. Além da admiração imensa que tenho pela sua obra - pequena quando comparada à de seu marido, Antônio Candido - Gilda me fascinou pela escrita luminosa e pela elegância, no modo de vestir e no trato com as pessoas. Sua história pessoal e profissional me fez ver a história intelectual brasileira pelo prisma das relações de gênero. Sobretudo na área de pensamento social, que até bem pou- co tempo, tratava o pensamento como um domínio sem gênero.

Como você avalia o seu doutorado e que importância ele teve na sua carreira? Como ele se liga (ou não) com a sua tese de livre-docência publicada na belíssima edição da EDUSP (2010) com o título "Intérpretes da metrópole. História social e relações de gênero no teatro e no campo intelectual, 1940-68", traduzido em 2016 para o espanhol e publicado na Argentina pela editora universitária de Quilmes? No livro, você se concentra nos momentos de reconfiguração do campo intelectual e da cena teatral, nos quais ocorrem diversificações dos perfis de agentes, observando seus deslocamentos, usos de certos trunfos, redes de sociabilidades e afetos, invenção de repertórios, etc. Por que escolheu trabalhar com teatro nesse livro?

Para responder à primeira parte da pergunta, sobre a importância que o doutorado teve na minha carreira, volto à sua publicação em 1998, pela Companhia das Letras. Destinos mistos: o grupo clima em São Paulo (1940-1968) ganhou dois prêmios, o mais honroso deles atribuído pela ANPOCS, na categoria de melhor obra científica em ciências sociais editada em 1998. Com o doutorado e com o reconhecimento que o livro teve, ganhei a confiança necessária para ousar novos projetos e inclui o teatro como assunto de pesquisa. Intérpretes da metrópole: história social e relações de gênero no teatro e no campo intelectual, antes de virar livro, foi escrito para ser apresentado e defendido como tese no concurso de livre-docência que fiz na UNICAMP em junho de 2008.

Animada pela recepção positiva da tese, encaminhei a tese para EDUSP. Aprova- 
da para publicação pela comissão editorial, presidida na época pelo editor e professor Plinio Martins Filho, o livro foi preparado por Ana Novais, minha amiga e integrante do setor editorial da EDUSP. Ela e Plínio são responsáveis pela edição caprichada (repleta de fotos de atrizes, atores, diretores, intelectuais), com prefácio de Antônio Arnoni Prado e contracapa de Maria Arminda do Nascimento Arruda. Eu fiquei felicíssima com o livro. Ele foi tema de entrevistas, recebeu um prêmio e duas distinções: "melhor obra científica" atribuída pelo "Concurso Brasileiro ANPOCS de obras científicas e teses universitárias em ciências Sociais - edição 2011"; Menção honrosa na categoria "Literatura brasileña" (não ficção) da "Edición 53 del Premio Literario Casa de Las Americas" 2012; finalista do 53 Prêmio Jabuti na categoria melhor livro em Ciências Humanas, atribuído pela Câmara Brasileira do Livro em setembro de 2011.

No livro procurei avançar no entendimento dos constrangimentos decorrentes das relações de gênero com o auxílio do contraste e da comparação entre o campo intelectual e a cena teatral. Voltei à trajetória de Gilda, examinada à luz das trajetórias de Lúcia Miguel Pereira e Patrícia Galvão, com foco no livro de estreia das três. Depois comparei com as carreiras das atrizes que se destacaram em São Paulo nos decênios de 1940 e 1950: Cacilda Becker, Tônia Carrero, Maria Della Costa, Fernanda Montenegro, Nydia Lícia e Cleyde Yáconis. Nesse período, São Paulo se tornou o polo modernizador do teatro brasileiro e "as mulheres, mandavam no teatro", nas palavras de atriz Maria Della Costa.

Gilda de Mello e Souza, Lúcia Miguel Pereira e Patrícia Galvão se inseriram num campo marcadamente masculino e sofreram, com maior ou menor intensidade, os reveses dessa condição. Valendo-se do capital cultural conquistado por meio de uma escolarização elevada ou de relações sociais entranhadas na atividade cultural, fizeram "nome" como críticas e ensaístas. Já as atrizes ganharam fama e firmaram a autoridade artística num domínio menos culto e escolarizado, e bem mais aberto à presença feminina. Mais "feminino" que o campo intelectual no período, o teatro ilumina, por contraste, os espaços possíveis, os recursos utilizados, os constrangimentos enfrentados por Gilda de Mello e Souza, Patrícia Galvão e Lúcia Miguel Pereira para se fazerem reconhecidas. Isto não significa que as clivagens de gênero estivessem ausentes do teatro. $\mathrm{Na}$ divisão de trabalho que presidia a carpintaria teatral na época, elas estavam lá, mas com inflexões distintas.

Enquanto o trabalho de ator era facultado a homens e mulheres, o da dramaturgia era privilégio ou atributo dos homens. Entre o polo mais "feminino" da representação, ocupado por atores e atrizes, e o mais "masculino" da dramaturgia, exercido pelos autores, encontravam-se os diretores e as ensaiadoras, com claro e diferenciado reconhecimento para os primeiros. Nos grupos e nos elencos, a figura da primeira atriz, remodelada pelas concepções do teatro moderno, continuou a ter uma grande centralidade, mesmo quando o nome dela não vinha estampado no nome da companhia. $\mathrm{Pa}-$ ra a manutenção de tal centralidade, as mulheres fizeram valer a competência adquirida como atrizes, com a anuência e apoio de seus parceiros.

Bastante distinta era a situação vivida pelas críticas e ensaístas. Não que os nomes delas - ou pseudônimo, como Mara Lobo, com o qual Patrícia Galvão estreou na ficção - não tenham sido estampados nos livros que escreveram. Tampouco que não 
pudessem galgar posições mais sólidas, decorrentes da autoria e da autoridade intelectual a ela associada, caso de Lúcia Miguel Pereira. E, sim, que as instâncias de controle e de prestígio, ocupadas prioritariamente pelos homens, só seriam franqueadas às intelectuais, como mostra a trajetória de Gilda de Mello e Souza, bem mais tarde e de forma muito mais tortuosa do que a enfrentada pelos seus colegas da profissão.

Em síntese e para não me alongar mais na resposta à pergunta que vocês fizeram, diria que meu objetivo foi o de não encapsular as trajetórias das mulheres reais sob o feixe anêmico de uma suposta condição comum de sujeição. Por isso o que busquei nessa visada comparativa foi por em relação trajetórias, carreiras, parcerias, constrangimentos e recursos alocados em espaços sociais específicos. Um desses espaços são campos de produção cultural, marcados por clivagens internas de gênero. Assim, ao refletir sobre as maneiras e as razões que levaram o campo intelectual e a cena teatral a serem mais (ou menos) refratários à presença e à atuação das mulheres nas décadas de 1940 e 1950, no período em que ambos se inscreviam numa mesma trama cultural, urdida pelas metrópoles em expansão (São Paulo e Rio de Janeiro), voltei, de esguelha, ao assunto que me levou a escolher a antropologia como profissão e ao feminismo como objeto do meu mestrado e minha primeira pesquisa de fôlego.

Em que redes de pesquisa você estava inserida quando escreveu a tese de livre-docência?

A pesquisa e a escrita de Interpretes da metrópole envolveram pessoas, instituições, grupos de pesquisa, sem os quais o meu trabalho não seria possível. A co- meçar pelos meus colegas do Departamento de Antropologia da UNICAMP, que me permitiram conciliar a pesquisa com a docência. Eles me concederam um ano de afastamento para realizar o pós-doutorado na Universidade de Stanford, durante o segundo semestre de 2001 e primeiro semestre de 2002, com o apoio de uma bolsa de pós-doutorado do CNPq.

Durante os 10 meses que passei nos Estados Unidos - na companhia de Sergio, que estava como fellow no Instituto de Altos Estudos de Palo Alto, de meu filho e dos filhos dele - pude voltar aos resultados do doutorado para "testar" uma análise comparativa da vida intelectual em São Paulo e Nova York. Graças aos acervos fantásticos das bibliotecas da Universidade de Stanford, em especial da Green Library que permitia o livre acesso às estantes, fui me enfronhando na leitura de trabalhos voltados para a história e a sociologia da vida intelectual e cultural de Nova York. Em especial do círculo de intelectuais responsável pela publicação da Partisan Review.

A consulta a dicionários e repertórios bio-bibliográficos, acrescida pela leitura de memórias e ensaios autobiográficos de autoria dos intelectuais que integravam a revista ou gravitavam a sua volta, constitui uma documentação preciosa. Tanto para que eu pudesse situar o lugar dessa publicação na carreira de seus autores, como para recuperar uma espécie de "diálogo" interno, às vezes cifrado, outras nem tanto, que mantiveram uns com os outros. No início de 1970, como resultado do envelhecimento de vários deles, do questionamento que sofreram por parte das gerações mais novas, sobretudo daquelas ligadas à nova esquerda, e da publicação, em 1976, das memórias da escritora e dramaturga Lillian Hellmann, Scoundrel time (1976), eles voltaram à cena 
editorial. Uma grande parte dos livros que escreveram traz uma reconstrução do passado que enfatiza o alinhamento deles no campo político do anti-stalinismo, numa tentativa de se demarcarem do anticomunismo desenfreado dos conservadores de direita e de sublinhar a importância que tiveram na cena cultural e política. Essas memórias são uma fonte inestimável para entendermos o tipo de sociabilidade que praticavam, as fofocas que circulavam na época, os amores, os casamentos e as separações, os conflitos, as inimizades, as alianças e as relações de gênero.

Essa incursão pela cena intelectual nova-iorquina deu origem ao primeiro capítulo de Intérpretes da Metrópole, no qual lanço mão de um dispositivo comparativo e contrasto os "nova-iorquinos" da Partisan Review aos "paulistas" da revista Cli$m a$ (1941-44) com especial atenção às relações de gênero.

De volta ao Brasil em 2002, elaborei um novo projeto de pesquisa, encaminhado ao $\mathrm{CNPq}$ na categoria "bolsa de produtividade em pesquisa”, que, aprovado, resultou nos três últimos capítulos desse livro. A Fundação de Apoio ao Ensino e à Pesquisa da UNICAMP também me concedeu um auxílio para que eu pudesse levar adiante a pesquisa sobre o ator e diretor de teatro Louis Jouvet, assunto do terceiro capítulo, feita antes da estadia na Califórnia. Em janeiro de 2001, passei um mês em Paris, pesquisando na Bibliothèque Nationale François Mitterand. Depois disso, voltei várias vezes à $\mathrm{Pa}$ ris, mas sem vínculo institucional e sempre por períodos curtos.

Mariza Corrêa, minha orientadora no mestrado, foi responsável pela inquietação analítica que deu origem a Intérpretes $d a$ metrópole, escrito primeiro para ser uma tese de livre-docência. Inspirada por seus es- critos e estimulada pelo seu pensamento vigoroso, escrevi a tese num diálogo pontilhado por bilhetes, dicas de bibliografia, trocas de textos e almoços animados com ela. Nesse período ela estava coordenando no Pagu (Núcleo de Estudos de Gênero da UNICAMP), o projeto "Gênero, Corporalidade", financiado pela FAPESP na modalidade Projeto Temático, entre 2004 e 2009. Convidada para integrar a equipe, foi assim que me liguei formalmente ao Pagu como pesquisadora. 0 projeto foi desenvolvido com Guita Debert, Maria Filomena Gregori, Adriana Piscitelli, Margareth Lopes e Júlio Assis Simões. Seu objetivo geral, amplo o suficiente para comportar os interesses intelectuais de todos nós, era o de analisar o modo como as características tidas como femininas e masculinas perpassam as convenções e normatizações sobre o corpo e, ao mesmo tempo, permeiam saberes e práticas. Motivada pelas discussões da equipe e dos seminários que congregavam também os nossos orientandos e orientandas, fui dando forma à tese, defendida um ano antes da finalização desse projeto.

A articulação analítica e empírica entre a história social da cultura, a etnografia das relações de gênero e a sociologia da vida intelectual ganhou uma amplitude maior com a participação, entre março de 2009 e fevereiro de 2013, no Projeto Temático FAPESP "Formação do campo intelectual e da indústria cultural no Brasil contemporâneo”, coordenado por Sergio Miceli. Integravam a equipe, Maria Arminda do Nascimento Arruda, Marcelo Ridenti, Lilia Schwarcz, Esther Hamburger, Luiz Jackson, Heloisa Buarque de Almeida, Alexandre Bergamo, Fernando Pinheiro e eu. Além da equipe, o projeto reuniu em torno de quarenta estudantes de mestrado e doutorado que participavam das reuniões mensais, voltadas para a 
discussão dos trabalhos da equipe, dos alunos e de livros e ensaios de autores relevantes para o adensamento teórico e metodológico da pesquisa. Essas reuniões eram feitas na FFLCH da USP e quatro dos meus orientados na época participaram ativa e assiduamente delas.

0 projeto procurou investigar as transformações decisivas por que passou a história social da cultura brasileira por meio de uma confluência temática original: a busca das conexões entre os surtos estratégicos de produção cultural erudita e a expansão de setores dinâmicos da indústria cultural. Ao lado das publicações individuais de cada um dos integrantes da equipe, o resultado mais expressivo do projeto encontra-se no livro que Sergio Miceli e eu organizamos, Cultura e Sociedade. Brasil e Argentina, publicado pela EDUSP em maio de 2014. Como sinalizei na orelha que escrevi para o volume (integrado por ensaios de toda a equipe), a apreensão das relações entre sociedade e cultura exige esforços interpretativos de fôlego e hipóteses arriscadas. Atiçados pela busca das conexões entre os surtos renovadores da produção cultural erudita e a expansão fenomenal da indústria cultural, os 13 ensaios do livro ressaltam os fluxos e a circulação de linguagens, ideias, modelos expressivos, obras e autores entre os diversos nichos do gradiente entre "baixa" e "alta" cultura no Brasil e na Argentina. Em lugar do sobrevoo generalista, atam o molde explicativo ao registro sensível do material: o itinerário do escritor Lima Barreto; a emergência das vanguardas modernistas - no Brasil e na Argentina; o surto do romance social e introspectivo, mesclado aos relatos emocionantes e às constrições lucrativas da nascente indústria editorial; a gênese da sociologia em ambiente universitário, prensada entre o ensaísmo de feitio literário e as exigências dos métodos científicos; as relações de gênero encenadas nos palcos e na televisão; os conflitos entre concepções divergentes sobre o trabalho intelectual e a atividade jornalística; as representações distintas sobre o valor literário legítimo, enfeixadas pelo fenômeno Paulo Coelho. 0 resultado é uma história social arrojada da cultura e da sociedade brasileira, potencializada pela comparação com o que sucedia na Argentina em domínios precisos, tensionados pela batalha dos gêneros, pela voz, sexo e abismo dos autores que embaralharam o panteão literário.

Juntando a sua experiência nesse projeto coordenado por Sergio Miceli com o livro que vocês organizaram ao último capítulo do Intérpretes da metrópole - e, na nossa opinião, um dos melhores, mais instigantes e sensíveis do livro - sobre as parcerias de trabalho e amorosa, como você vive esse parceria afetiva e intelectual com Sergio?

0 assunto das parcerias, que apareceu de esguelha no meu doutorado, foi tratado longamente, como disse antes e vocês reforçaram, em Intérpretes da metrópole, pelo prisma tanto das assimetrias, visíveis no campo intelectual do período, quanto das criações compartilhadas, que implicam, muitas vezes, em desigualdades de poder, ligadas ao maior ou menor reconhecimento dos parceiros nelas envolvidos. No caso das atrizes que pesquisei, o renome que elas conquistaram é inseparável de suas parcerias amorosas e de trabalho. Com essa afirmação não pretendi diminuir o brilho e o talento dessas atrizes, tampouco minimizar a dedicação com que construíram suas carreiras. 0 que quis mostrar é que elas viveram uma situação distinta da que era experimentada pelas 
mulheres intelectuais nas décadas de 1930 e 1960. As intelectuais, como mostrei no livro com o auxílio da análise de trajetórias, enfrentaram uma série de constrangimentos para se afirmar e "fazer nome". Entre eles, a conciliação da carreira com a família. $\mathrm{Ou}$, quando casadas com intelectuais de renome, tiveram que lidar com os conflitos reais e imaginários de sentirem ou serem vistas à "sombra" dos maridos. Isso não aconteceu com as grandes atrizes da época, como Cacilda Becker, Tônia Carrero, Fernanda Montenegro, Lydia Lícia, Maria Della Costa, que foram alçadas à condição de protagonistas com a anuência e respaldo dos parceiros. Seguindo a tradição no meio teatral do auto-empresariamento, elas criaram suas companhias, nas quais figuraram como principal chamariz, enquanto os parceiros atuaram como diretores, intérpretes, empresários, mesclando às vezes as três atividades. É preciso frisar, no entanto, que as razões para o empenho diverso dos "significant others" (parceiros, maridos ou amantes) não consistem em disposições pessoais isoladas, explicáveis por "temperamento" ou "boa-vontade”. Residem antes nas dinâmicas particulares dos campos de produção simbólica, mais (ou menos) refratários às inflexões de gênero e à atuação das mulheres.

Claro que essas questões não se puseram apenas como resultados de interesses intelectuais desencarnados da minha experiência. Elas reverberam em registro analítico e com o recurso deliberado do distanciamento ao estudar períodos distintos do meu, o que vivi em relação à minha parceria amorosa e de trabalho com Sergio. Por isso, me permito fazer aqui uma nota mais pessoal.

Eu tinha 30 anos quando comecei a namorar o Sergio. Hoje tenho 61. Isso significa que metade da minha vida está ligada à dele, em todas as dimensões. Quando o co- nheci, ele tinha 44 anos e liderava a equipe da História das Ciências Sociais. Nosso primeiro encontro foi uma entrevista, como já disse antes. Eu me preparei para a entrevista porque queria muito participar daquele projeto. Li o livro Intelectuais e classes dirigentes, na edição da Difel, e achei surpreendente o prefácio do Antônio Candido. Na apreciação do livro, Candido, fugindo ao procedimento habitual nesse tipo de empreitada que é o de destacar as qualidades e o valor do trabalho e do autor sobre os quais se está prefaciando, aponta algumas restrições ao livro. Após sublinhar a sua novidade no tocante à interpretação do papel dos intelectuais brasileiros, Candido chama atenção para o "perigo das análises desse tipo". Qual seja: "o perigo de misturar desde o começo do raciocínio a instância da verificação com a instância da avaliação”.

Achei a frase de Candido esplêndida e cheguei na entrevista com ela na ponta da língua. Sérgio, além de me perguntar sobre os motivos de querer participar da equipe e o que eu tinha em mente como proposta de pesquisa, se inteirou, por mim mesma, que eu havia lido o livro com o qual ele se doutorou (aqui e na França). E quis saber a minha opinião. Não tive dúvidas: sapequei a frase de Candido. Metida, disse que concordava inteiramente com ela (rsss). Temi pela reação, na hora pensei: que ousadia boboca. Para quem queria tanto participar desse projeto, eu tinha dado um tiro no pé. Mas bastou alguns segundos para eu perceber que Sergio se divertiu com a minha petulância, me entregou dois enormes relatórios do grupo e, como já contei, me deu uma semana para ler tudo e para encontrar um assunto que se adequasse aos interesses da pesquisa.

Esse primeiro encontro deu o tom da nossa relação. Da minha parte, um misto de fascínio pela inteligência do Sergio e gosto 
pela polêmica (e pelo embate). Quando começamos a namorar eu não tinha nem começado o doutorado. Passados 31 anos, fiz a carreira completa, me tornei professora titular, dei, por assim dizer, as provas públicas de competência e investimento na vida universitária. Ao longo desse tempo, experimentei com Sergio as implicações dos constrangimentos e inseguranças, mas também das conquistas e avanços na carreira e no trabalho intelectual. A diferença de idade entre nós - 14 anos - que parecia imensa no início da nossa relação, hoje não tem muita importância, pois de uma certa maneira e descontado o alcance distinto dos nossos trabalhos, nos tornarmos mais simétricos. Ele não escreve nada sem que eu não leia depois. 0 mesmo vale para mim. Mas hoje as avaliações críticas que ele costuma fazer - comigo, com os colegas, com os orientandos - não me deixam mais sem chão. "Qual é o argumento? ”- essa pergunta que Sergio fazia em todas as discussões dos textos da equipe da História das Ciências Sociais sintetiza a maneira dele interpelar.

A primeira vez que ele discutiu um texto meu numa das reuniões coletivas da equipe da História das Ciências Sociais eu fiquei arrasada. Seguindo a prática que ele imprimiu no grupo, cada um dos participantes opinava sobre o texto e o autor tinha que ouvir tudo calado, sem responder "pois o que não está resolvido no texto, não se resolve com a palavra" - outra das frases do Sergio que se tornaram emblemáticas no grupo. Os elogios que recebi do historiador Fernando Novais pelo primeiro texto que apresentei para ser discutido pelo grupo (sobre as coleções brasilianas) não foram suficientes para aplacar o desconcerto que as críticas de Sergio produziram em mim. As- sim que cheguei em casa (não tinha celular na época), liguei aos prantos para a minha amiga querida, Bibia (Maria Filomena Gregori). Antes que eu pudesse explicar a razão do choro, ela achou que tinha acontecido alguma coisa com meu filho, João, então com três anos, tamanha a minha aflição! Visto de hoje, é risível, mas dá bem a ideia da diferença entre nós dois no início da nossa relação.

No decorrer da carreira, com o aumento da confiança em mim mesma e sem a insegurança que me atormentou no mestrado e no início da vida profissional, fui aprendendo a lidar com o embaço e os enguiços das assimetrias com mais calma e, diria até, sabedoria. Sergio, como escrevi na dedicatória de Intérpretes da metrópole, iluminou a minha vida. Juntos fizemos muitas coisas e construímos uma relação a um só tempo amorosa e de trabalho, marcada pela admiração recíproca. A vida dele é inseparável do trabalho. Não à toa, ele escreveu mais de vinte livros, organizou equipes, liderou projetos, formou um número expressivo de doutores, alguns excelentes, como a Camila, por exemplo. Eu também trabalhei muito. Mas não posso dizer que o trabalho é o centro da minha vida, ainda que de fato talvez seja.

A passagem do tempo me permitiu experimentar aquilo que um dos personagens de Guimarães Rosa expressou com tanto acerto: "envelhecer devia de ser bom, a gente ganhando maior acordo consigo mesmo" Não só pelo ajuste sincrônico com a minha própria experiência de envelhecimento, mas, sobretudo, pela maneira de vivê-la na sintonia da concordância consigo mesmo. Nove anos de análise, uma compreensão menos implacável e mais generosa com meu 
"tamanho" na vida e na profissão, somada à decisão de me aposentar após 34 anos como professora na UNICAMP, me deram a tranquilidade necessária para experimentar novos projetos na vida. Com a aposentadoria, continuei ligada ao que a Universidade tem de melhor - meus colegas e alunos - sem a obrigação semanal de me deslocar de São Paulo para a Campinas. Me livrei da estrada e de todos os pesadelos associados a ela. Para quem perdeu a mãe num desastre de automóvel, vocês podem imaginar a dureza que foi passar quase 40 anos (se incluir o tempo do mestrado) indo e vindo pela Bandeirantes, a estrada de nome tão paulista, da minha casa em São Paulo para a UNICAMP. Me aposentei em abril de 2018. Neste mesmo ano dei início ao meu novo projeto de pesquisa, apoiado com a bolsa de produtividade do CNPq: "Casas, domesticidade, experiência urbana e subjetividade na metrópole". Se a cidade, a produção cultural e a experiência social eram o cerne dos projetos anteriores; neste, as casas, a domesticidade e a subjetividade ganham o primeiro plano. Não podia imaginar o quanto isso se tornaria uma experiência mundial com a quarentena, a crise sanitária e o distanciamento social impostos neste ano de 2020 pela pandemia da Covid-19.

Para dizer bem sinteticamente, o objetivo inicial desse projeto é o de analisar a maneira como a literatura produzida em São Paulo entre os anos de 1940 e 2000 retratou o entrelaçamento dessas dimensões. A utilização da ficção como fonte principal da pesquisa segue a tese de Raymond Williams de que "a experiência da cidade é o método da ficção: o método da ficção é a experiência da cidade". Com o auxílio da literatura, quero entender as mudanças em curso ao longo desse período nas concepções sobre as casas, seus significados e suas ligações com a experiência social, com as reordenações espaciais da cidade, com as práticas e representações da domesticidade e das relações familiares. Casas, como mostra a literatura antropológica, são artefatos que expressam visões de mundo e maneiras de estar no espaço. Apreendidas em sua diversidade arquitetônica e urbanística, histórica, sociológica e etnográfica, as casas envolvem a produção e a internalização de princípios hierárquicos, dispositivos classificatórios e mecanismos de subjetivação, atiçados e enredados pelos marcadores sociais de gênero, classe, raça e geração.

Num registro mais pessoal e psicanalítico, vejo hoje que o assunto da casa tem ligação (elementar, meu caro Watson!) com a minha "volta para casa”, depois da aposentaria. E também com uma conciliação, digamos assim, com as figuras femininas marcantes da minha vida: minha avó materna, minha mãe e Eunice - que, para se firmar na carreira que ela abraçou com determinação (a linguística), relegou a casa e a domesticidade a uma hierarquia menor na constelação de seus interesses. E com isso volto, a partir de novos lugares e posições, às figuras masculinas fundamentais da minha vida (meu pai, Hélio Pontes, Sergio, meu filho, João, e meus irmãos, Claudio, Luís André, Carlos André e Flávio, que desistiu da vida em 2009). Mas chega de falar da minha vida pessoal. Hora de mudar de assunto!

Nos seus estudos, você se valeu do referencial teórico analítico da sociologia de Pierre Bourdieu, mas se desfez da rigidez de uma sociologia da cultura bourdieusiana ortodoxa incorporando Norbert Elias, Raymond Williams e também estudos etnográficos, finamente assimilados com as atividades de docência, nos cursos que deu de antropologia 
e na orientação de alunos. 0 que vemos é que essa prática atraiu mestrandos e doutorandos interessados em diversos domínios, como cinema, moda, edição, música, literatura, fotografia, vida intelectual, mas não apenas no campo artístico/cultural. Por isso e para terminar, gostaríamos que você falasse sobre o seu trabalho como orientadora.

Orientar, ensinar e pesquisar são o ponto alto da vida universitária. Eu tive - e continuo a ter - a sorte de orientar um grupo talentoso de alunos ao longo desses 24 anos, desde que me doutorei em 1996 ${ }^{9}$. Oito dos meus orientandos foram premiados por seus trabalhos. Taniele Rui e Gustavo Rossi ganharam os Prêmios Capes de Tese na área de Antropologia. Taniele, em 2013, com a tese "Corpos abjetos: etnografia em cenários de uso e comércio de crack"; Gustavo Rossi, em 2012, com a tese "0 intelectual 'feiticeiro: Édison Carneiro e o campo de estudos das relações raciais no Brasil”. Alexandre Zarias recebeu o "Prêmio Anpocs-Cnpq", em 2004, com a dissertação "Negócio público e interesse privado: análise antropológica dos processos de interdição”. Dois orientandos de iniciação científıca, Felipe Bier Nogueira e Stela Politano, receberam a Menção Honrosa concedida pela Pró-Reitoria de Pesquisa da UNICAMP. Renato Brolezzi, autor da monografia “A construção da realidade: Sílvio Rome- ro e a busca da identidade nacional”, foi premiado no II Concurso de Monografia de alunos dos Cursos de Graduação do IFCH, realizado em 1991. E Ana Carolina Rodgher ganhou, em 2018, no mês em que me aposentei, o XXV. "Concurso Fausto Castilho de Monografias” (realizado no IFCH, UNICAMP) com "O Olhar de Charcot: ensaio sobre a modernidade, a fotografia médica e o encontro da clínica com a histeria”.

Assim e para encerrar esta entrevista longuíssima, quero reafırmar a importância da universidade na produção do conhecimento, na troca intergeracional, na formação qualificada de pesquisadores e intelectuais comprometidos com a ciência, com a democracia, com a inclusão social. Em que outro lugar a curiosidade é estimulada e partilhada com tamanho vigor? Não a curiosidade que procura assimilar o que convém conhecer, mas aquela que, nas palavras precisas de Foucault, "nos permite separar-nos de nós mesmos. De que valeria a obstinação do saber - indaga-se o filósofo - se ele assegurasse apenas a aquisição dos conhecimentos e não, de certa maneira e tanto quanto possível, o descaminho daquele que conhece?"10

\section{Recebida em: 15/05/2020 \\ Aprovada em: 10/06/2020}

9. Para não cometer injustiça, nomeio todos: Graziele Luiza Rossetto, Felipe Bier Nogueira, Stela Politano, Mariana Pulhez, Renato Brolezzi, Débora Stucchi, Jean Carlo Faustino, Thuany de Figueiredo, Daniel Simião, Patrícia Sant'Anna, Cauê Krüger, Daniela Scridelli, Mônica Ribeiro, Maria Patrícia Ferreira, Daniela Araújo Silva, Rita de Cássia Farias, Luísa de Oliveira, Sabrina Finamori, Alexandre Zarias, Luis Felipe Sobral, Gustavo Rossi, Rodrigo Ramassote, Taniele Rui, Vitor Teixeira, Marcos Pedro Rosa, Jonatan Sacramento, Thais Lassali, Ana Elisa Carneiro, Ana Carolina Rodgher, Gabriela Limão, Brunela Succi. Nathanael Araújo, Tatiana Massaro, Rafael do Nascimento Cesar. Além deles, supervisionei três pós-doc: Gustavo Rossi (com quem tenho uma parceria estreita e dei meu último curso na pós-graduação, antes de me aposentar), Andrea Ciacchi e Bernardo Fonseca.

10. Cf. Foucault, História da sexualidade: o uso dos prazeres, Rio de Janeiro, Graal, 1984, p.13 
